\title{
Decisions of the European Court of Human Rights for the Respect of Article 6 of the Convention against Albanian state
}

\author{
PhD Ina Foto Barjamaj \\ PhD student at Institute of Europe, University of Tirana \\ Email: ina.puravell@yahoo.com \\ Prof.Assoc. Dr. Alba Dumi \\ Director of Graduate School, Business Department, "Ismail Qemali" University, Vlore, Albania \\ Economy Faculty, Business Department, Tirana, Albania \\ Email:alba.besi12@gmail.com
}

\section{Doi:10.5901/mjss.2015.v6n1p80}

\begin{abstract}
This paper studies the cases of judicial practice, seeing in the light of Article 6 of the European Convention on Human Rights and in particular regarding the execution of judicial decisions. Albania often mentions the importance of reforming the justice system in order to strengthen the rule of law. But very little is said about reforming the Bailiff Service who carries the brunt of enforcement of judicial decisions, whether criminal or civil. What role will play a judicial decision if he would be not implemented? This paper brings attention to judicial matters that are reviewed by the ECHR against the Albanian State. By analyzing those aims to bring out the need for immediate intervention of the state that should play through its mechanisms, in strengthening the position and the image of the bailiff service, in increase the number of executive titles and increased the cooperation of different agency in the framework of the implementation of final judicial decisions. Once a court system that functions is only he who is applied, otherwise justice would remain an illusion. The execution of the decision is an integral part of the decision itself. In order to seek a solution to the situation in accordance with the standards of Strasbourg
\end{abstract}

Keywords: Execution of judicial decisions, the European Court of Human Rights, the judicial practice; reform; European standards, European Charter of Human Rights.

\section{Introduction}

The aim of this article is to present an overview of execution of court decisions in the Republic of Albania, seeing in the light of decisions which are given by the European Court of Human Rights. European Court of Human Rights is a court which reviews requests for violation of the provisions of the European Charter of Human Rights. By extending its authority to the European Union member states as well as for those that are not parts of the union, but have ratified the European Convention and its Protocols. The process has a contradictory characters counting on the evidence that the parties bring before this court. Since 1959 when the European Court of Human Rights has started its activity, the number of decisions has been increasing showing the role that this institution plays in the well-functioning and respecting the human rights in the European Union, but not only. The jurisprudence of this Court has played a major role not only for the member states, which are affected by decisions given. This paper focuses more on the decisions that are given to violations of the right provided for by Article 6 of the European Convention: The right of due legal process ". Part of the right to a due process is the execution of court decisions. The need for such a study arose from the desire to understand the importance of execution of a judicial decision. Referring to the decisions of the European Court, we receive a feedback about how European jurisprudence conceives the execution of court decisions for this reason part of this paper is to review some decisions of the European Court and their way of reasoning.

In order to implement these decisions and necessary concepts, so these can be part of internal legal framework, and therefore to transform the current system by making it more efficient and productive, like the standards of European Union. 


\subsection{Article 6 of the European Convention on Human Rights, its meaning and importance}

This convention was drafted by the Council of Europe. It was opened for signature in Rome on November 4, 1950, and entered into force on 3 September 1953. Taking as starting point the Universal Declaration of Human Rights of 1948, the drafters of the Convention sought to pursue the goals of the Council of Europe by maintain and further realize the rights and fundamental freedoms.

Besides presenting a catalog of civil and political rights and freedoms, the Convention also created a mechanism for execution of duties of the Contracting States. This responsibility were assigned to three institutions: the European Commission for Human Rights (established in 1954), the International Court of Human Rights (established in 1959), and the Council of Ministers of the Council of Europe, where the latter consists of Ministers of Foreign Affairs of the Member States or their representatives.

With the entry of new member states since 1990, the number of cases has increased significantly. This has been one of the reasons why in 1998 the Protocol 11 of the ECHR entered in force. The aim of this protocol was to shorten the procedures but empowering at the same time the judicial character of the system making it fully compulsory and abolishing judicial responsibility of the Council of Ministers. ECHR consists of an equal number of judges of Contracting States (currently forty-five).

Judges become part of the Court in their individual capacity. Judges are elected for a term of nine years by the Parliamentary Assembly of the Council of Europe and cannot be re-elected. During their tenure Judges shall not engage in any other activity which is not in accordance with their independence, impartiality or with the demands of working full time. ECHR as an interpretive authority of the Convention plays a vital role in creating the internal jurisprudence, in particular for the Constitutional Court, in accordance with the standards of the ECHR. At the national level ECHR decisions have an erga omnes effect, whatsoever the decision of the ECHR is inter partes, but for a single case, not necessarily the Albanian state should pass the same Calvary, therefore the state should take into consideration the effects of the decision on the same case.

\subsection{Principles of the procedure which is based on the ECHR}

ECHR supports the principle of the rule of law. Including the principle of objectivity, that means to interpret the law without privileged any party. The court is a transparent institution in decision making and that has envisioned special mechanisms for the execution of decisions, and do not leave it to the arbitrariness of state. ECHR can deal with the matter only after being exhausted all the domestic legal remedies, according to generally rules accepted from the international law, and within a period of six months from the date of the final decision. According to her, the exhaustion of domestic remedies is not absolute, nor can be implemented automatically ${ }^{1}$. In assessing whether are exhausted all legal possibilities effective by the court, always has been important to determine what appropriate means were available to the injured party if they have created the real possibility, for settling disputes effectively².

An application may be submitted by either the Contracting State (State application) or by an individual who claims to be the victim of a violation by one of the High Contracting Parties of the rights set forth in the Convention and the Protocols. An individual application that is not in accordance with the provisions of the Convention or the protocols, clearly unfounded, or is an abuse of the right of application or where the applicant has not suffered a significant violation would be considered unacceptable. If the judge does not declare an application as unacceptable or does not reject, the application will be forwarded to a Council or the Chamber for further examination.

Council may decide, by unanimous vote, to declare as unacceptable or to reject an application, and this can do without further review. In case of acceptance of this Council can take a decision on the merits, if the case filed in the case concerns the interpretation or application of the Convention or the Protocols, and there is already a precedent in court. The right to a fair trial is not only the acceptance and the progress of the process, but also the execution of the decision: "The execution of the decision given by any court must be considered as part of the" trial "for the purposes of Article 6" of the European Convention of Human Rights, so the right of access to the court "would be an illusion if the legal system of the State allows a final decision to remain unexecuted at the expense of one party"3.

Execution of the decision of the court is considered to be an integral part of the fundamental human right to a fair trial within a reasonable period, in accordance with Article 8 of the European Convention on Human Rights The

${ }_{1}^{1}$ Akdivar dhe te tjere kunder Turqise, vendim i dates 16.09 .1996

2 Ugurlukoci kunder Republikes Federale Gjermane, vendim i dates 12.03.1987

${ }^{3}$ Citimi nga Gjykata Evropiane për Mbrojtjen e të Drejtave të Njeriut është nga rasti i vitit 1997 Hornsby kundër Greqisë 
conference of European Ministers of Justice of the Council of Europe agreed that "proper, effective, and efficient court decisions is of utmost importance to States in order to create, strengthen and develop a system of strong and respected judiciary". Therefore, it is not surprising that the development of the jurisprudence of the Court in recent years has seen a huge increase in cases of execution of judgment (final) or judgments and other obligatory documents of the court. The number of cases before the ECHR, especially in countries in transition, is still seen as an indicator for the state in development of the rule of law, particularly in the area of justice, all cases adds the interest of countries to improve the efficiency of the execution systems.

\section{Methodology}

The method used in this paper is that of reviewing it case by case of the case law, according to the decisions taken by the ECHR. Having extracted from this analysis, the problems that are found by the court in violation of Article 6 of the right to fair trial. Problematic that from year to year is added for Albanian state and is focused on some key aspects of law, such as that of property restitution and compensation, of indemnifying, in family law, like meeting the child etc. Recognition of these decisions and their review would help in improving the current situation of the execution of judgments.

In the case Gjyli against Albania, the European Court notes that the Albania Constitutional Court's decisions have recognized the violation of decisions of domestic courts. However it was a declaratory judgment, so the Constitutional Court did not provide any appropriate corrections. Moreover it is not awarded any compensation for material and immaterial damages, and even that could be offered a clear perspective prevention of the infringement ${ }^{4}$. From the above analysis of the issues with the finding of infringement object of due process due to non-execution of judicial decisions. We suggest changes to the Organic Law of the Constitutional Court, in order to define the complete and clear rules for the right of compensation in case of finding a violation.Also the creation of a special monitoring body for the execution of the decisions of this nature.

\section{Cases of Jurisprudence of the ECHR}

H1. Problems that is found by the Court in violation of Article 6 of the Convention in relation to the lack of enforcement.

In 1997, in the landmark case Hornsby against Greece, the ECHR decided by seven votes in favor and two against a violation of Article 6 paragraph 1 of the ECHR by the administrative authorities of Greece, and is expressed:

"Last practice of the court, Article $6 \S 1$ secures to everyone the right to have claims concerning for the civil rights and obligations before a court or tribunal; in this way she embodied "the right to a court", an aspect which constituted the right to start the process before the court for civil matters. However, this right would be illusory if the judicial system allows Contracting States to not execute a final court decision. It would be unprecedented if Article 6 / 1 should describe in detail procedural guarantees provided for litigants, trials that would be fair, public and expeditious - without protecting the implementation of judicial decisions; interpretation of Article 6 if it was exclusively for access to court proceedings and development will likely lead to situations incompatible with the principle of the rule of law, which the Contracting State is committed to respect, when they ratify the Convention. Written by experts in the field, each handbook deals with one aspect of the European Convention on Human Rights or its protocols. They were written with legal practitioners, and particularly judges, in mind, but are accessible also to other interested readers.

Therefore, the execution of the judgment given by any court in this case had to be regarded as part of the "trial" for the purposes of Article 6. Moreover the Court had already accepted this principle in cases of trial duration. ${ }^{5 "}$ This document describes how the Council of Europe mechanisms pertaining to human rights and the rule of law have helped to bring about genuine improvements in legislation, practice and the situation of individuals in the member States

In case Burdov against Russia ${ }^{6}$ ECHR concluded that lack of funds is not a reason for not respecting the debt: "It is not open to the State authority to cite lack of funds as a reason for not paying a debt. Undoubtedly, a delay in the execution of the decision may be justified in certain cases. But the delay may not be large enough to completely undermine the essence of the law under the provisions of Article $6 \S 1$. The "Human rights files" series is aimed at specialists in European law: lawyers, practitioners and research students.

It also constitutes a useful resource for the implementation of the European Convention on Human Rights in the signatory states.In the present case, the applicant did not have to stumble to benefit from the success of the lawsuit,

${ }^{4}$ Gjyli against Albania , paragraph 58

${ }^{5}$ Hornsby kundër Greece; GJEDNJ Mars 19, 1997; numër 107/1995/613/701

${ }_{6}^{6}$ Shih Burdov kundër Rusisë, 7 maj 2002, kërkesa nr. 59498/00 
which had intended to compensate the damage caused to his health in the case of mandatory participation in an emergency operation, arguing assumed financial difficulties experienced by the State. "

H2. Coming ever-increasing number of implementation issues that judicial decisions are reviewed by the Court in connection with the Albanian State.

\section{Cases of Albania to the European Court of Human Rights}

The right of human rights and freedoms are very important for each person. To respect them is an obligation for a state that wants to be democratic, so that institutions and the right will be consolidated. Rights and fundamental freedoms are enshrined in the Constitution of Albania, as the highest law of the state. As part of these rights is also the right for a trial within a reasonable time. This principle is essential to not delay the trials indefinitely and that the right of the person is placed within a short time, in order not to lose efficiency and the importance of the right itself.

Even the right to a fair hearing, is part of human rights and plays an important role for their protection, which has a direct impact on judicial activity. The execution of a final decision of the court is considered as the final stage of realization of the right. Only after realizing this phase can be considered that the individual has fully set in place the right to win.

Albania joined the Council of Europe on 13 July 1995 as 35. The state has ratified the European Convention on Human Rights October 2, 1996. Since then, Albania is a party to numerous cases before the ECHR. Until 2009, the ECHR has received 22 judgments in cases against Albania. In a number of cases the ECHR has found violations of the Convention and / or protocols. At least three of these cases have been on the basis that the State has failed to comply or enforce a final decision. European Court, by decision dated November 18, 2004 Qufaj Co. Sh.PK against Albania, no. $54268 / 00$, has addressed the problem of non-enforcement of court decisions in Albania.

In the present case, the Municipality of Tirana had granted permission for a commercial building site, but no construction permit for apartment buildings. As a result of significant losses in its commercial activities, the company sued the Municipality of Tirana in Tirana District Court seeking financial compensation of 60 million leks. After rejection by this court, the company appealed to the Court of Appeal which ordered Tirana Municipality to pay society ALL 60,000,000 amount. As a result of the failure that recourse to the High Court, the aforementioned decision became final. Since this decision was not executed, the company complained to the Constitutional Court which rejected the request on the grounds that the execution of judicial decisions was outside its competence. Delay in execution of a decision cannot be justified if it is detrimental to the essence of the right protected in the sense of Article $6 \S 1$ of the Convention.

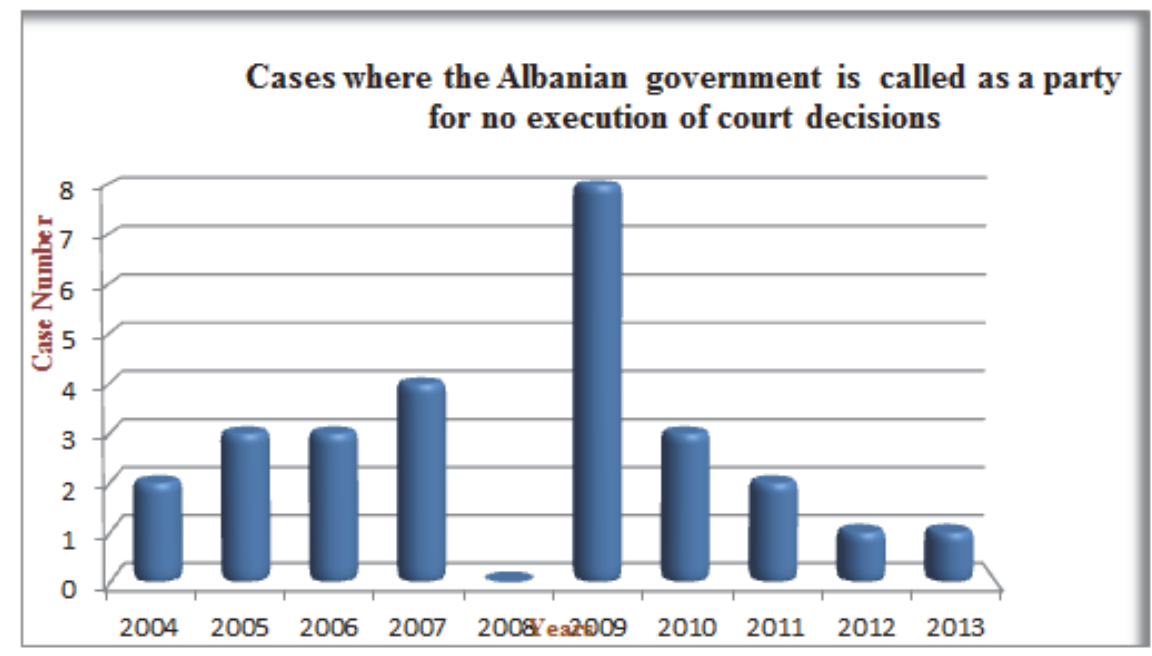



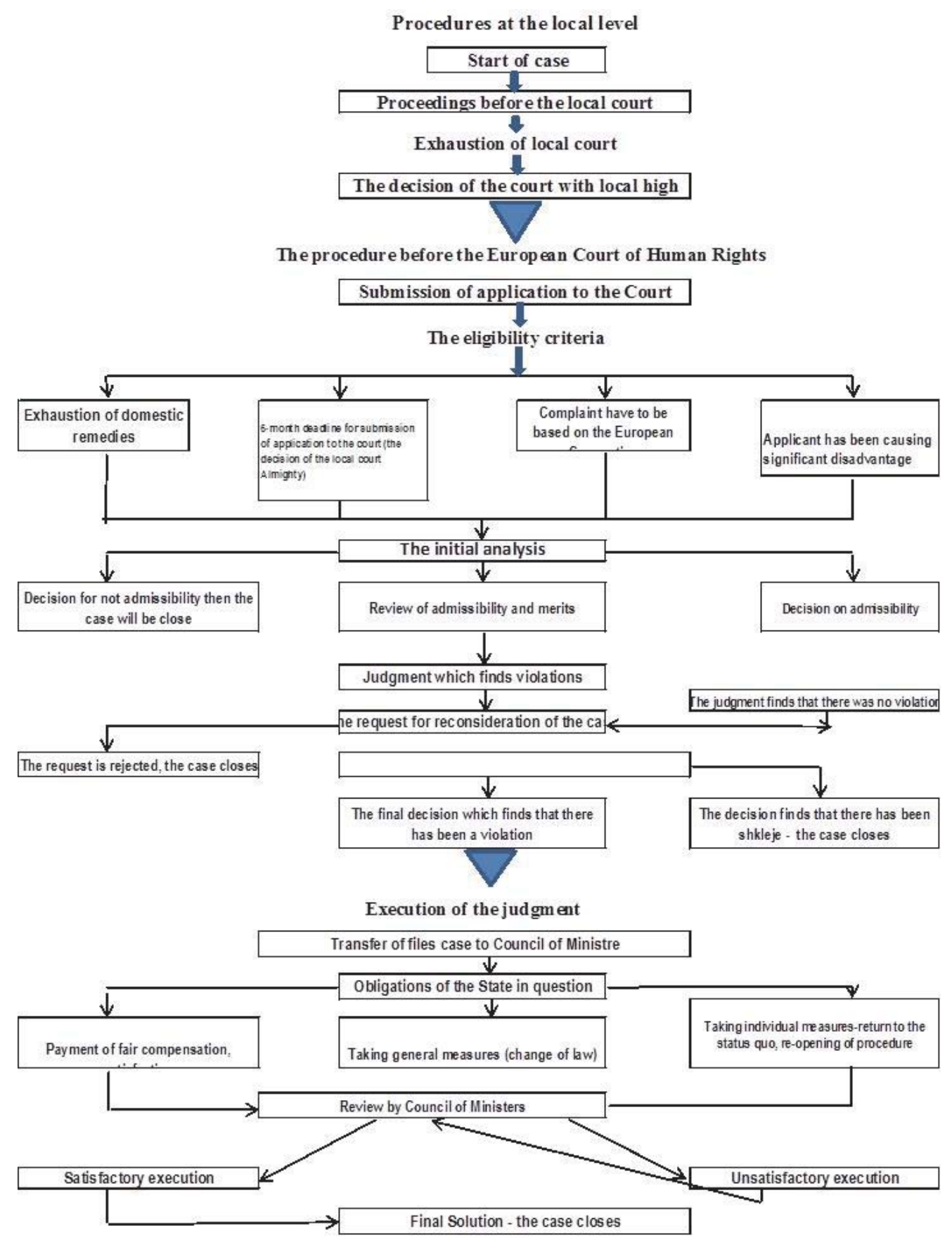

\section{Objectives}

Increasing the number of court cases against the Albanian state testifies to the internal legislator for the importance of strengthening not only the legal framework but also the institutional too, in order to strengthen the Bailiff Service. Accurate analysis of the decision will help us to make this necessary reform and improvement the current situation of Albanian. However, this court emphasizes the restitution in integrum principle, because as stated that the Convention has been violated, based on Article 1, she has the right to fair compensation to the injured party, when the internal law allows only partial correction of consequences caused by the violation. The aim is not only the ascertainment of cases, but to take action in order to improve the situation of the execution in the Albania society. 
In case Driza v Albania ${ }^{7}$ the ECHR had to decide in a case where the final decision of the Supreme Court of Albania had not been executed for more than six years. The Court stated that the Government had not provided any explanation as to why this decision of 7 December 2000 was not executed even after more than six years after it was established, and the bailiff or administrative authorities had not taken any steps to enforce the decision. Therefore, one should be aware that Albania is in a unique situation when it comes to cases where the court should decide cases based on the so-called "Law on Restitution and Compensation of Property". These cases are in fact dealing with the redistribution of land and compensation for lost land. Execution of decisions in these cases is one of the most urgent issues of the Government of Albania. The Strasbourg Court has already mentioned several times Albania,

"... As a matter of urgency, to take all appropriate legal, administrative and budgetary, to ensure that the Applicant Party" in a quickly way "to get compensation or be given land ... These issues should include the establishment of an adequate fund to pay a financial compensation to the applicants whose are entitled."

In the case Beshiri and others against Albania ${ }^{8}$ has to do with the failure of the execution of final court decisions April 11, 2001 to the applicant's right to compensation for the land parcel which was nationalized (violations of Article 6§1 ECHR and Article 1 of Protocol 1 of the ECHR).

Citing a lack of state funding, as did the government, it did not justify the situation. Moreover, after the failure of the decision of 11 April 2001 the national authorities have put applicants in an unclear situation for property restitution cases, and for a considerable time, he has made it impossible for those receiving compensation and use their money. Ignoring decisions, state authorities do not control or improve themselves with a system of 'balancing of powers ", and fail to help to improve the rule of law. In a system that lacks instruments to materialize these rights that certainly deserve protection, such as the right to enforce the judgment. In some cases, the way the court does not provide an effective solution for individuals who claim that their rights have been violated, resulting in the need for help in the unfair solution.

The number of cases of non-executed shows that Albania currently has no only a typical problems of enforcement caused by inefficiency, disregard of the property rights or non-funding of existing services, but also lacks the financial means in order to respect the obligations, which arise from judgments against the state.

In the case Bajrami against Albania ${ }^{9}$ applicant daughter was taken from her mother in Greece without his consent. On 22 February 2004 the Vlora District Court has approved the divorce of the applicant and gives him custody of the child. Although the applicant has taken steps to ensure the return of the girl, the decision was never executed. According to the executive office of the agent, it was impossible to apply because the child was not in Albania.

The ECHR noted that Albania had not ratified the relevant instruments to reunite parents with their children, including the Hague Convention of 1980 on the Civil Aspects of International Child Kidnapping. But, regardless, the ECHR found that the Albanian legal system, as it was, did not provide an alternative framework that would provide the applicant a practical and positive protection required by States under Article 8 of the ECHR. (Albania joined the Hague Convention, which entered into force on 1 August 2007.)

In a later case, Nuri against Albania, the property rights of the applicants were accepted by the Commission for restitution. Since the plot of land cannot be returned, the applicant was right to receive compensation. Once other property was returned to the applicant, had not yet received compensation. Although the applicant had not exhausted all national possibilities, the Court considers that there has been a violation of Article 6 of the Convention. Despite the obligation, the state had failed to provide instruments to organize appropriate return. Of course, the ECHR did not provide an expanded explanation of its decision; the Court did not think that should give an explanation after it had determined that there had been a violation of Article 6 of the Convention. ECHR simple referred to relevant cases from the past: Ramadhi against Albania, and Ramadhi and others against Albania.

\section{Conclusions and Recommendation}

The execution of judicial decisions is a key element in the functioning of the state based on the rule of law. It constitutes a serious challenge both at national and European level.

The number of cases of execution of a final judgment is increase before the ECHR, especially in countries in transition. Previous decisions of the ECHR should serve as an incentive for the execution of court decisions from internal institutions like and should be seen as an indicator of the state in development of the rule of law.

\footnotetext{
7 Shih GJEDNJ, 13 Nëntor 2007; kërkesa nr. 3371/02

${ }^{8}$ Beshiri dhe të tjerët kundër Shqipërisë, 22 gusht 2006 (Kërkesa nr. 7352/03)

${ }^{9}$ Bajrami kundër Shqipërisë, 18 dhjetor 2007 (Kërkesa nr. 35853/04)
} 
As a result of this paper me suggest:

- created a working group on enforcement of judgments (CEPEJ GT-EXE), which is tasked to develop guidelines for the effective application of existing standards of the Council of Europe

- changes to strengthen the Bailiff service in order to avoid as far as possible the Albanians state financial punishment by the ECHR

- changes to the Organic Law of the Constitutional Court

- define the complete and clear rules for the right of compensation in case of finding a violation

- creation of a special monitoring body for the execution of the decisions of this nature, but also of other decisions that may show the failure problem

The number of cases of non-executed shows that Albania currently has no only a typical problems of enforcement caused by inefficiency, disregard of the property rights or non-funding of existing services, but also lacks the financial means in order to respect the obligations, which arise from judgments against the state.

\section{References}

The Constitution of Albania State

Toska.E "Albanian Constitutional Court as an effective remedy under the European Convention on Human Rights in relation to nonexecution of judicial decisions final "Albanian magazine for legal studies, Vol 12011

Council of Europe "European Court of Human rights: summaries of selected decisions restitution / compensation of properties" , 10 February 2011

USAID Agency for International Development, System Enforcing Agreements and Decisions, Training Manual: Civil Permberimit International Standards, October 2011

GJEDNJ, 13 Nëntor 2007; kërkesa nr. 3371/02

GJEDNJ, 18 dhjetor 2007; Kërkesa nr. 3738/02

Qufaj Co. sh.p.k kundër Shqipërisë, 18 nëntor 2004 (Kërkesa nr. 54268/00)

Beshiri dhe të tjerët kundër Shqipërisë, 22 gusht 2006 (Kërkesa nr. 7352/03)

Bajrami kundër Shqipërisë, 18 dhjetor 2007 (Kërkesa nr. 35853/04)

Gjyli kundër Shqipërisë, 29 shtator 2009, kërkesa nr. 32907/07.

rasti Puto kundër Shqipërisë, 22 nëntor 2010, kërkesa nr. 609/07

Gjyli kundër Shqipërisë, 7 dhjetor 2010, kërkesa nr. 32907/07

Nuri kundër Shqipërisë, 3 shkurt 2009 (Kërkesa nr. 12306/04)

Vrioni dhe të Tjerët kundër Shqipërisë", nr. 2141/03, datë 24.03.2009 (Kërkesa nr. 2141/03)

Dauti dhe të Tjerët". Rasti nr. 19206/05 datë 03.02.2009 (Kërkesa nr. 19206/05) 